\title{
Introduction to the Symposium on the Science and Politics of Glyphosate
}

\author{
Alessandra ARCURI* and Yogi Hale HENDLIN**
}

\section{THE ORIGINS}

Glyphosate is the most widely used pesticide in history, ${ }^{1}$ and it is one of the most contested in current regulatory science and politics. As a commercial product, glyphosate has the dubious distinction of joining an infamous club - along with cigarettes - of products that have had multibillion dollar Master Settlement Agreements concluded against them to allegedly amend for the health harms and deaths of hundreds of thousands of product users, while still being legally available on the market. ${ }^{2}$

Originally developed to kill weeds, the first genetically modified (GM) crops were created not to boost vitamin A or provide some other essential nutrient, but instead to withstand the application of glyphosate without dying. ${ }^{3}$ While only since around 2015 has glyphosate become a household name, the agricultural significance of the chemical and the controversies surrounding it date back decades. The first seven grams of glyphosate were originally synthesised in 1950 without a specific purpose by a Swiss scientist working for the small company Cilag, which later sold a

\footnotetext{
* Inclusive Global Law and Governance, Erasmus School of Law and Erasmus Initiative Dynamics of Inclusive Prosperity, Erasmus University Rotterdam, Rotterdam, The Netherlands. We would like to thank the Erasmus University Rotterdam's Dynamics of Inclusive Prosperity Initiative and Institute for Public Knowledge for their financial and organisational support for the 6 June 2019 "The Science and Politics of Glyphosate" Workshop that Yogi Hale Hendlin and Alessandra Arcuri organised, which occasioned this special issue and the development of this article. We have no conflicts of interest to disclose.

** Dynamics of Inclusive Prosperity, Erasmus School of Law, Erasmus University Rotterdam, Rotterdam, The Netherlands and Environmental Health Initiative, University of California, San Francisco, CA, USA; email: hendlin@esphil.eur.nl.

1 See CM Benbrook, "Trends in Glyphosate Herbicide Use in the United States and Globally" (2016) 28 Environmental Sciences Europe 3.

2 M Givel and SA Glantz, "The 'Global Settlement' with the Tobacco Industry: 6 Years Later" (2004) 94 American Journal of Public Health 218; J Sier, "Bayer Shares Climb after \$11B Roundup Settlement" (MarketWatch, 25 June $2020)<$ https://www.marketwatch.com/story/bayer-shares-climb-after-11b-roundup-settlement-2020-06-25> (last accessed 28 June 2020). The Bayer settlement is not yet finalised. See P Cohen, "Judge Puts Cloud over Settlement of Roundup Cancer Claims" (New York Times, 7 July 2020) < https://www.nytimes.com/2020/07/07/business/ roundup-lawsuit-settlement.html > (last accessed 24 July 2020).

3 A Szekacs and B Darvas, "Forty Years with Glyphosate" in MN Hasaneen (ed.), Herbicides - Properties, Synthesis and Control of Weeds (London, InTech 2012) <http://www.intechopen.com/books/herbicides-properties-synthesisand-control-of-weeds/forty-years-with-glyphosate> (last accessed 11 March 2020); SM Druker, Altered Genes, Twisted Truth: How the Venture to Genetically Engineer Our Food Has Subverted Science, Corrupted Government, and Systematically Deceived the Public (1st edn, Salt Lake City, UT, Clear River Press 2014); A Arcuri and YH Hendlin, "The Chemical Anthropocene: Glyphosate as a Case Study of Pesticide Exposures" (2019) 30 King's Law Journal 234.
} 
collection of patents that became owned by Monsanto. ${ }^{4}$ Twenty years later, Monsanto scientists discovered glyphosate's phytotoxic properties, and the broad-spectrum systemic herbicide became commercialised..$^{5}$ In 1974, Roundup, the first glyphosatebased herbicide $(\mathrm{GBH})$ to be sold, entered the market. In recent years, roughly $50 \%$ of the Monsanto corporation's (bought by Bayer in 2018 for US\$63 billion) earnings came from this agrichemical, which is used in over 750 products, most notably Roundup and Ranger. ${ }^{6}$ Being the "first billion dollar product" of the pesticide industry, ${ }^{7}$ glyphosate has been christened the rock star of pesticides. ${ }^{8}$ In recent years, when Monsanto's glyphosate patent ran out, many other competitors started to sell glyphosate, reproducing and magnifying its commercial life. ${ }^{9}$

This cursory diachronic account illustrating the immense financial intertwinement of glyphosate as the touchstone pesticide for GM crops and the agribusiness industry also reflects how history, science, law and policy have become inextricably linked. As GM organisms (GMOs) have attracted major controversies, so has glyphosate, in part because, for policy decisions, policy wars over glyphosate have often served as proxies for questions over the legitimacy and desirability of GMOs. But again, this particular entanglement is just one of many. Glyphosate as a pure solitary chemical does not exist in the real world of use and application. In everyday practice, glyphosate is inextricably related to adjuvants and various co-formulants; the life of glyphosate is in admixtures. ${ }^{10}$

To discuss the current state of glyphosate in terms of its science, law and policy, on 6 June 2019, we convened a remarkable group of policymakers, scientists and social scientists at Erasmus University Rotterdam, sponsored through the Dynamics of Inclusive Prosperity Initiative. ${ }^{11}$ This rare dialogue across such traditionally siloed disciplines shed light on the science and politics of this substance and its orbit of regulatory issues in its complexity (rather than serially or separately) regarding how science may inform and be used to politically manoeuvre on chemical regulatory

4 RL Zimdahl, A History of Weed Science in the United States (1st edn, Amsterdam, Elsevier 2010) p 105; VK Nandula (ed.), Glyphosate Resistance in Crops and Weeds (1st edn, Hoboken, NJ, Wiley 2010) p 1.

5 Glyphosate was first sold to Aldrich, a chemical company, which resold it in 1960 to Monsanto; see Zimdahl, supra, note 4 , at 105 .

6 AM Henderson et al, "Glyphosate General Fact Sheet" (National Pesticide Information Center, March 2019) $<$ http://npic.orst.edu/factsheets/glyphogen.html> (last accessed 29 June 2020); J Latham, "University of California System Halts Use of Glyphosate Herbicide" (Independent Science News | Food, Health and Agriculture Bioscience News, 17 May 2019) <https://www.independentsciencenews.org/news/university-of-california-system-halts-use-ofglyphosate-herbicide/> (last accessed 27 May 2019).

7 A Székács and B Darvas, "Forty Years with Glyphosate" in MN Hasaneen (ed), Herbicides: Properties, Synthesis and Control of Weeds (London, Intech 2012) pp 247-84.

8 A Arcuri, "Glyphosate" in J Hohmann and D Joyce (eds), International Law's Objects (Oxford, Oxford University Press 2018) pp 234-46.

9 At least $40 \%$ of all glyphosate worldwide is now produced by Chinese companies. CM Benbrook, "Trends in Glyphosate Herbicide Use in the United States and Globally" (2016) 28 Environmental Sciences Europe 3.

10 For an in-depth discussion of the "chemical imaginary" of isolated glyphosate as regarding regulatory structures versus the cocktail of chemicals and adjuvants admixing in actual commercially available formulas, see in this Special Issue Hendlin et al, "Like Oil and Water: The Politics of (Not) Assessing Glyphosate Concentrations in Aquatic Ecosystems".

11 See Workshop, The Science and Politics of Glyphosate, organised by A Arcuri and YH Hendlin, Erasmus Initiative Dynamics of Inclusive Prosperity <https://www.eur.nl/en/research/erasmus-initiatives/dynamics-inclusive-prosperity/ events/science-and-politics-glyphosate $>$ (last accessed 24 July 2020). 
issues, as well as how politics inflects the experimental design and interpretation of toxicology assessments. As the paradigmatic chemical for regulatory and toxicology assessments, the glyphosate saga, with its ramifications in both scientific debates and regulatory decision-making, provided a productive exchange, resulting in this Special Issue.

\section{A CASCADE OF Disputes}

Glyphosate for decades has been viewed as a miracle herbicide, being provisionally considered a safer and more environmentally friendly compound than DDT or other agrochemical options. ${ }^{12}$ But mounting evidence for the past two decades began to question the assumption of minimal, acceptable toxicity. ${ }^{13}$ The accumulating tensions in the scientific debate came to a head when the International Agency for Research on Cancer (IARC) - the specialised cancer agency of the World Health Organization (WHO) - issued Monograph 112 in 2015, ${ }^{14}$ classifying glyphosate as a "probable carcinogen" for humans and finding sufficient evidence of carcinogenicity in experimental animals. The report generated global front-page media coverage and a number of disputes between various chemical regulatory agencies worldwide.

On its face, these disputes relate to the question of which scientific studies were right or wrong. Directly after IARC issued its March 2015 finding of probable carcinogenicity, domestic agencies such as the American Environmental Protection Agency (EPA) and the European Food and Safety Authority (EFSA) came out with similar safety assessments, but they came to slightly different conclusions, demurring from such a strong classification as that of IARC. The precipitating regulatory disputes occurred on multiple levels.

The first dispute occurred at the level of regulatory scientific authorities, upon reviewing each other's assessments. Parallel, involved scientists started a skirmish debate, which is ongoing in academic journals of different sorts, on the methods that should be used for these assessments. Journalists, representatives of civil society and lawyers followed suit. In this context, documentary evidence was disclosed, possibly suggesting that Monsanto had been lobbying together with front groups for months to push for quick and favourable retorts to the IARC report by government agencies where Monsanto (now Bayer) had contacts in order to diffuse the likely unfavourable outcome from IARC. ${ }^{15}$

\footnotetext{
12 SO Duke and SB Powles, "Glyphosate: A Once-in-a-Century Herbicide” (2008) 64 Pest Management Science 319.

13 Y Kim et al, "Mixtures of Glyphosate and Surfactant TN20 Accelerate Cell Death via Mitochondrial DamageInduced Apoptosis and Necrosis" (2013) 27 Toxicology In Vitro 191; B Hedlund, "Lawyers: CRT Correction of Glyphosate Review Only Tells Half the Story" (Baum Hedlund, 27 September 2018) <https://www.baumhedlundlaw. com/9-18-journal-correction-monsanto-review/> (last accessed 28 August 2019); C Gasnier et al, "Glyphosate-Based Herbicides Are Toxic and Endocrine Disruptors in Human Cell Lines” (2009) 262 Toxicology 184; J George et al, "Studies on Glyphosate-Induced Carcinogenicity in Mouse Skin: A Proteomic Approach" (2010) 73 Journal of Proteomics 951.

14 See IARC Monograph 112, 2015 <http://monographs.iarc.fr/ENG/Monographs/vol112/> (last accessed 27 February 2017) (hereafter "Monograph 112"); Guyton et al, "Carcinogenicity of Tetrachlorvinphos, Parathion, Malathion, Diazinon, and Glyphosate" (2015) 16 Lancet Oncology 490.

15 Monsanto's (correctly) predicted response that IARC would find glyphosate to be toxic has to do with IARC's prioritisation of writing monographs only on substances that already have a large and growing literature on the
} 
One particularly bitter dispute concerned the alleged dishonesty of certain assessments. ${ }^{16}$ Allegations were made that certain agencies were too close to industry and that the assessment of safety depended more on these relations than on the science as such. And indeed, in at least one well-documented case, experts found that the key evaluation conducted in Europe by the Federal Institute for Risk Assessment (Bundesinstitut für Risikobewertung (BfR)) in Germany was vitiated by plagiarism. ${ }^{17}$ And not plagiarism of just any kind, but plagiarism of industry studies, which the agency was supposed to have independently evaluated. ${ }^{18}$ Such allegations only served further to confuse and muddle disputes over the state of glyphosate toxicology science and issues regarding misconduct in the process of scientific assessment. Both issues, now inextricable, led the European Union (EU) to relaunch its compromised evaluation of glyphosate, and now it has entrusted a group of EU Member States to cooperatively complete this assessment, due before the next re-authorisation phase in 2022.

Disputes morphed and mushroomed in the legal arena. In the USA, at least a couple of developments warrant note. First, when the State of California decided to list glyphosate as carcinogenic, ${ }^{19}$ its decision was unsuccessfully challenged in court. ${ }^{20}$ Second, a wave of costly lawsuits (up to 125,000) have been launched by citizens (mainly farmers, groundskeepers and other glyphosate applicators, or family members of deceased

health harms and are already pre-selected for assessment because of their potential societal harm. For original Monsanto documents on efforts at lobbying the EPA and EFSA, see R Vinas, "RE: EFSA Comments Proposal" (Grocery Manufacturers Association 2017) jybn0226 <https://www.industrydocuments.ucsf.edu/chemical/docs/ \#id=jybn0226> (last accessed 28 May 2019); A Overstreet, "[Email from Overstreet Anne about Glyphosate IARC]" (2015) qypl0226 <https://www.industrydocuments.ucsf.edu/chemical/docs/\#id=qypl0226> (last accessed 28 May 2019); D Farmer and M Koch, "[Email from Heydens, William F to Koch, Michael S Regarding IARC Planning]" (2015) gxmn0226 < https://www.industrydocuments.ucsf.edu/chemical/docs/\#id=gxmn0226> (last accessed 30 May 2019); Secondary literature on the discrepancies between IARC and EFSA/EPA's assessments include: H Vainio, "Public Health and Evidence-Informed Policy-Making: The Case of a Commonly Used Herbicide" (2020) 46 Scandinavian Journal of Work, Environment \& Health 105; CJ Portier et al, "Differences in the Carcinogenic Evaluation of Glyphosate between the International Agency for Research on Cancer (IARC) and the European Food Safety Authority (EFSA)" (2016) 70 Journal of Epidemiology and Community Health 741.

16 See supra, note 15 for examples.

17 S Marks, "Researchers accuse German authority of plagiarism in glyphosate review" (Politico, 15 January 2019) $<$ https://www.politico.eu/article/bfr-glyphosate-germany-researchers-accuse-german-authority-of-plagiarism-inglyphosate-review > (last accessed 30 May 2019); S Weber and H Brutscher-Schaden, "Detailed Expert Report on Plagiarism and superordinated Copy Paste in the Renewal Assessment Report (RAR) on Glyphosate" (2019) $<$ https://www.greens-efa.eu/files/doc/docs/298ff6ed5d6a686ec799e641082cdb63.pdf> (last accessed 30 May 2019); see also Stefan Grobe, "Researchers accuse German authority of plagiarism in glyphosate review" (Euronews, 17 January 2019) <https://www.euronews.com/2019/01/17/researchers-accuse-german-authority-of-plagiarism-inglyphosate-review $>$ (last accessed 30 May 2019).

18 A Report, commissioned by the EU Parliament, found over 50\% of the BfR assessment was copied from the Glyphosate Task Force's own assessment of other published studies and $\sim 80 \%$ of the chapters relevant to the assessment of industry studies were copied directly from industrial studies; see Weber and Burtscher-Schaden, supra, note 17 .

19 <https://oehha.ca.gov/proposition-65/crnr/glyphosate-listed-effective-july-7-2017-known-state-california-causecancer $>$ (last accessed 23 May 2019).

20 JJ Graefe, “Glyphosate's Fate: Comparing Strategies for the Precautionary Cancellation of Glyphosate Registrations in the United States and the European Union" (2020) 35 Connecticut Journal of International Law 251; Center for Biological Diversity, "California Becomes First State to Declare Glyphosate Causes Cancer" (EcoWatch, 30 March 2017) <https://www.ecowatch.com/california-roundup-cancer-warning-2335205128.html> (last accessed 2 July 2020). 
applicators) against Monsanto/Bayer. ${ }^{21}$ The first verdict was in favour of Benicia School District groundskeeper DeWayne Johnson who, as part of his job, sprayed hundreds of gallons of GBHs daily. The California State Court found that the GBH Roundup caused Johnson's non-Hodgkin's lymphoma and ordered Monsanto to pay Johnson US\$289 million (verdict given in August 2018). ${ }^{22}$ After initial awards of over US $\$ 2$ billion in the single Pilliod v. Monsanto Company case, now owner of Monsanto Bayer's stock dropped by a third (roughly $€ 30$ billion), imperilling the company and causing Bayer's investors to second-guess the wisdom of the Monsanto acquisition just a few months prior. Bayer lost $€ 57.7$ billion in market capitalisation directly after these lawsuits, almost as much as the price of its purchase of the Monsanto company, in what one commentator called the "biggest destruction of capital in German stock market history". ${ }^{23}$ With such enormously high stakes, it is no wonder that there has been significant and organised opposition to open and transparent science, policy and regulation around this - and similar - chemical(s).

Bayer and its investors saw the ballooning class action suit of what would eventually become a settlement on 24 June 2020 (although this is yet to be fully concluded) and decided to cut its losses. Hit on every side by angry investors questioning the sense of the Monsanto purchase with so much legal exposure (which investors believed Bayer should have been aware of), Bayer saw a settlement as an opportunity to kill three birds with one stone. The three achievements of the settlement for Bayer included: (1) not just resolving $75 \%$ of the 125,000 open glyphosate non-Hodgkin's lymphoma cases against it (excluding those exposed to Roundup that had already filed a lawsuit), ${ }^{24}$ but also (2) indemnifying against the water contamination suits from toxic polychlorinated biphenyl (PCB) compounds that it faced, and (3) indemnifying against foreclose lawsuits about crop damage from drift from dicamba-based products (Monsanto/Bayer's glyphosate replacement weed-killer, which has proven so far to be even more toxic than Roundup) ${ }^{25}$ Bayer's stock shares have surged since the settlement, with Bayer CEO Werner Baumann praising the

21 For an extensive review of the history of how the US litigation developed, please see the article in this Special Issue: C Benbrook, "Shining a Light on Glyphosate-Based Herbicide Hazard, Exposures and Risk: Role of Non-Hodgkin Lymphoma Litigation in the USA". Also see: C Gillam, "Monsanto Roundup Trial Tracker - U.S. Right to Know" (US Right to Know, 25 April 2019) < https://usrtk.org/monsanto-roundup-trial-tracker-index/> (last accessed 23 May 2019); A Bronstad, "Bayer Agrees to Pay Up to \$10.9B to Resolve Roundup Lawsuits" (Law.com, 24 June 2020) < https://www.law.com/2020/06/24/bayer-agrees-to-pay-up-to-10-9b-to-resolve-roundup-lawsuits/> (last accessed 3 July 2020).

22 DeWayne Johnson v Monsanto Company, et al, No 3:2016cv01244 - Document 52 (ND Cal 2016) [2016]; S Levin, "The Man Who Beat Monsanto: 'They Have to Pay for Not Being Honest"' (The Guardian, 26 September 2018) $<$ https://www.theguardian.com/business/2018/sep/25/monsanto-dewayne-johnson-cancer-verdict $>$ (last accessed 2 July 2020).

23 RB Wisner, "Bayer CEO Open to Roundup Settlements Following Verdict and Stock Hit" (Baum Hedlund, 6 November 2018) <https://www.baumhedlundlaw.com/11-18-bayer-monsanto-roundup-settlement/> (last accessed 2 July 2020).

24 The settlement aimed to create a "standstill period" prohibiting plaintiffs in the class from filing new glyphosaterelated litigation against Bayer AG. C Gillam, "Challenge Eyed to Class Action Plan for Bayer Roundup Settlement" (U.S. Right to Know, 26 June 2020) <https://usrtk.org/uncategorized/challenge-eyed-to-class-action-plan-for-bayerroundup-settlement/> (last accessed 3 July 2020).

25 L Mulvany, "The Other Monsanto Chemical Bayer Investors Should Watch" (Bloomberg, 17 August 2018) $<$ https://www.bloomberg.com/news/articles/2018-08-17/the-other-monsanto-chemical-that-bayer-investors-shouldwatch $>$ (last accessed 1 May 2019); Sier, supra, note 2. 
settlement as "financially reasonable when viewed against the significant financial risks of continued, multiyear litigation and the related impacts to our reputation and to our business". ${ }^{26}$ Since Bayer's market value just before the settlement was just half of what it was in 2015 and some estimates of the exposure before the settlement had reached as high as US $\$ 800$ billion, ${ }^{27}$ the "relief" this settlement brings Bayer - which the Financial Times claims "Bayer can easily afford to pay" - may enable the continued sale of glyphosate while insulating Bayer from the significant exposure that has been hampering the company. ${ }^{28}$ What remains to be seen is whether this expensive lesson will in any way incentivise Bayer and other chemical manufactures to work deferentially with regulators, or if it will just precipitate a doubling down on defensiveness.

Meanwhile, in Europe, private citizens, non-governmental organisations (NGOs) and parliamentarians have challenged the secrecy of the evaluation conducted by EFSA and have been partly successful in obtaining the disclosure of key scientific studies. ${ }^{29}$ They have also mobilised new legal avenues to demand a ban on glyphosate through the European Citizens' Initiative (ECI) ${ }^{30}$ Moreover, the European Parliament set up a Special Committee on the Union's authorisation procedure for pesticides (PEST), which delivered a critical report identifying the key reforms needed for the current regulatory framework to enhance its level of transparency and its overall ambition in meaningfully addressing the toxicity of pesticides. ${ }^{31}$ It is at the intersection of all of these disputes, drawing on science, health, business and law, that this Special Issue can be situated.

\section{UNPACKING A DOUBLE-BARRELLED QUESTION: THE SCIENCE AND POLITICS OF}

\section{GLYPHOSATE}

The Workshop at Erasmus University brought together in the same workshop the scientific heads of both IARC and EFSA - a rare encounter that perhaps surprisingly demonstrated that the two agencies' assessments of glyphosate have more in common than they disagree on (as was often the perception presented in the media). The Workshop's keynote lecture by science and technologies studies (STS) pioneer Sheila

\footnotetext{
26 J Miller, "Bayer to Pay up to \$10.9bn to Settle US Roundup Lawsuits" (Financial Times, 24 June 2020) <https:// www-ft-com.eur.idm.oclc.org/content/e0c5844a-c97a-4d5e-a96a-3d6fc73b89d4> (last accessed 3 July 2020).

27 Wisner, supra, note 23.

28 Editors, "Bayer: Tort, a Lesson" (Financial Times, 25 June 2020) < https://www-ft-com.eur.idm.oclc.org/content/ 1c9d2433-d010-497b-aa90-5d17538881d8> (last accessed 3 July 2020).

29 See Case T-716/14, Anthony C. Tweedale v European Food Safety Authority [2019] ECLI:EU:T:2019:141; Case T-329/17, Heidi Hautala and Others v European Food Safety Authority [2019] ECLI:EU:T:2019:142. For an insightful comment on these cases, see M Morvillo, "The General Court Orders Disclosure of Glyphosate-related Scientific Studies: Tweedale, Hautala, and the Concept of Environmental Information in the Context of Plant Protection Products" (2019) 10(2) European Journal of Risk Regulation 419.

30 European Commission, "Press Release - Commission Registers 'Ban Glyphosate' European Citizens' Initiative" (Europa.eu, 2017) <http://europa.eu/rapid/press-release_IP-17-28_en.htm> (last accessed 27 February 2017); the ECI was registered on January 25 at <https://web.archive.org/web/20170726111432/https://ec.europa.eu/citizens-initiative/ public/initiatives/open/details/2017/000002/en> (last accessed 24 July 2020).

31 Special Committee on the Union's authorisation procedure for pesticides, Report on the Union's authorisation procedure for pesticides (2018/2153(INI)), A8-0475/2018, 18.12.2018.
} 
Jasanoff situated the glyphosate saga in a broader historical and socioeconomic context. In an interview during the Workshop, Jasanoff stressed that the controversies underpinning the glyphosate saga are related to different questions: if it is important to understand when science is right or wrong, it is equally important to ask how conclusions of rightness and wrongness can be reached in the first place. ${ }^{32}$ The contributions to this Special Issue partly unpack and help us to rethink this double- if not triple-barrelled question.

Marta Morvillo starts to unpack these questions by drawing attention to the concept of regulatory epistemology (meaning "the development of norms and practices for the management of knowledge, expertise and evidence in regulatory decision-making within a given institutional context"). ${ }^{33}$ Against this background, Morvillo exposes the limits of the linear risk analysis model underpinning much of EU risk regulation. In evaluating how the various disputes surrounding glyphosate may have contributed to reshaping the EU's regulatory epistemology, Morvillo finds that, despite some welcome developments enhancing transparency, reform has been modest. In particular, she focuses on the new General Food Law, which may prove underambitious because it seems to reiterate rather than radically challenge a linear risk analysis model. Yet, it is premature to draw general conclusions, especially pending the renewal of the approval of glyphosate in 2022.

At another level, glyphosate raises questions relating to the very constitutional architecture underpinning the European legal order, as lucidly illustrated by Ton van den Brink. ${ }^{34}$ In his contribution, Van den Brink problematises the dichotomy between legislative acts and executive rule-making, showing that the legal nature of the reauthorisation of glyphosate is not easily placed under the latter. In bold and yet nuanced reasoning, van den Brink concludes that the political dimensions of the glyphosate case may imply that the renewal of glyphosate is a matter for the legislature to decide. This is because the technical nature of some questions related to glyphosate cannot easily brush away some of the broader political questions on the type of agriculture that we want to embrace in the EU.

That the technical and the political are intertwined emerges also from the contribution by a group of scientists, toxicologists and lawyers (Robinson et al), who question the current procedures for risk assessment. ${ }^{35}$ Their analysis shows how political choices may be relevant for technical analysis. For example, a question that risk assessors (eg toxicologists working for EFSA) may have to resolve is how to evaluate contradictory studies. Should false positives or false negatives be minimised? According to the authors, a holistic application of the precautionary principle would demand the minimisation of false negatives; yet, in the practices followed by EFSA,

\footnotetext{
32 See interview with Prof S Jasanoff at Erasmus Initiative Dynamics of Inclusive Prosperity < https://www.youtube. com/watch?v=fQ_xJGpK8rk\&feature=emb_logo $>$ (last accessed 24 July 2020).

33 See in this Special Issue M Morvillo, “Glyphosate Effect: Has the Glyphosate Controversy Affected the EU's Regulatory Epistemology?".

34 See in this Special Issue T van den Brink, "Danger! Glyphosate may Expose Weaknesses in Institutional Systems: EU Legislation and Comitology in the Face of a Controversial Reauthorisation".

35 See in this Special Issue C Robinson et al, "Achieving a High Level of Protection from Pesticides in Europe: Problems with the Current Risk Assessment Procedure and Solutions".
} 
the opposite may have happened. One problem they identify is that the alleged neutrality of the methodologies used in the practice of risk assessment obscures important value choices. When most of these methodologies are developed in conjunction with industry - as they currently are according to the authors - then the likelihood that toxicity will be under-detected increases. The combination of practices that border misconduct with contestable methodological choices could help explain why "pesticides that have successfully passed through the authorisation process can cause harm to humans, animals and/or the environment". 36

Questions relating to the application of the precautionary principle are central to the recent ruling by the Court of Justice of the EU (CJEU) in Blaise and others. ${ }^{37}$ In this case, the CJEU was asked to rule on the compatibility of Regulation 1107/2009 with the precautionary principle. Sophia Paulini critically engages with the reasoning of the Court, concluding that CJEU's judgment can be faulted for appraising the Regulation "in a vacuum". ${ }^{38}$ In some sense, this critique resonates with the same critiques raised regarding the ways in which active substances are typically assessed in the lab, without much consideration of the real conditions under which they affect the environment. Paulini finds that, while the CJEU has clarified some important normative dimensions of the precautionary principle, in its judgment it was somewhat oblivious to the concrete issues arising in the daily implementation or application of Regulation 1107/2009.

While the EU courts have been mainly confronting questions related to the regulatory realm (and its limits), in the USA, the feedback loop between citizens becoming aware of the hazards of GBHs, the scientific research on the dermal and inhalation dangers of GBHs dwarfing harms from dietary ingestion and the work of investigative journalists to expose the decades-long lag between government and industry recognition of potential harms that could have been mitigated through labelling and other precautions drove litigation. During the 2018-2020 US glyphosate litigation, it was revealed that the US Environmental Protection Agency (EPA) Office of Pesticide Programs from 1984 to 1991 had already recommended that glyphosate be classified as a "possible human carcinogen", illustrating that IARC's 2015 designation indeed carried regulatory precedent. ${ }^{39}$ Agricultural economist Charles Benbrook reviews historical industry and regulatory documents made available through discovery during the US glyphosate litigation to indicate episodes of possible risk regulation, and he analyses the reasons given for demurring. Contrastive definitions of toxicity and narrow analysis of glyphosate or more comprehensive GBH admixtures were determinative in risk assessments. For example, while EPA's and Monsanto's assessments focused on pure glyphosate, substantial data exist showing that GBHs containing polyethoxylated tallow amine (POEA)-based surfactants (used in US formulations but phased out in Europe because it was found to be more toxic as a chemical than unadulterated glyphosate) actually cause substantial additional harms

\footnotetext{
36 ibid.

37 Case C-616/17, Blaise and others [2019] EU:C:2019:800.

38 See in this Special Issue S Paulini, "Fact or Fiction? Case C-616/17 and the Compatibility of the EU Authorisation Procedure for Pesticides with the Precautionary Principle".

39 Benbrook, supra, note 21.
} 
themselves and potentiate glyphosate's toxic profile when mixed together. ${ }^{40}$ While US litigation centred around glyphosate's risk for non-Hodgkin's lymphoma, clearly there are also other areas of risk.

While the determinative question for glyphosate regulation since 2015 has centred around the IARC's finding of the chemical's probable carcinogenicity, Vesco Paskalev argues that it is a historical accident that the international regulatory community has fixated on this determining factor rather than including and evaluating other health and environmental risks. ${ }^{41}$ Carcinogenicity, Paskalev argues, has served merely as a proxy for more complicated assessments, both scientific and political. Article 4 of the EFSA Plant Protection Products Regulation suggests that if a substance is declared carcinogenic, then it cannot be commercially sold; so carcinogenicity became a convenient battleground on which both industry and NGOs could engage, vastly simplifying the complex scientific and social questions involving the chemical and its effects. Paskalev discusses the advantages and disadvantages of regulating by proxy from both an epistemological and a regulatory side, and he stresses the inherently interpretative task of all regulatory agencies in making conclusions from and weighting various forms of scientific studies and independent and industry guideline studies. Arguing against hiding behind depoliticised regulation, regulatory agencies must give both ethical and scientific accounts for their decisions to shift the regulatory window in one direction rather than another.

One of the ways to turn regulatory emphasis beyond the carcinogenicity of glyphosate is to look at the effects of GBHs on aquatic environments. By shifting the frame from merely direct human health impacts to ecosystem and other organism impacts due to GBHs, both direct as well as indirect, scientific and political controversies do not dissipate; rather, these other sources of risk information provide more data points, allowing for more informed regulatory decisions. Arguing for regulatory agencies to take seriously their already on-the-books laws relating to chemical effects on aquatic environments and to look beyond compartmentalised and anthropocentric renderings of harm, Hendlin et al point to the lack of coherency and inter-agency communication in regulatory decision-making as impediments to rational decision-making. ${ }^{42}$ Correctly assessing exposures as they occur in application environments - in this case, focusing on water - and analysing actual admixtures of sprayed GBHs rather than just focusing on the toxicology of glyphosate alone may be difficult, but it better adheres to actual exposures rather than theoretical laboratory conditions. As a broadspectrum pesticide replete with adjuvants, the effects of GBHs on aquatic environments are measured according to direct and indirect effects, the latter of which are often excluded from water regulation analyses. Detailing the issues involved in EU water regulation and glyphosate, the authors generalise the issues encountered to how chemical risk assessments underemphasise environmental risks and how

40 See Commission Implementing Regulation (EU) 2016/1313 of 1 August 2016 amending Implementation Regulation (EU) No 540/2011 as regards the conditions of approval of the active substance glyphosate C/2016/4896 [2016] OJ L208.

41 See in this Special Issue V Paskalev, "The Clash of Scientific Assessors: What the Conflict over Glyphosate Carcinogenicity Tells Us about the Relationship between Law and Science".

42 Hendlin et al, supra, note 10. 
attending to the direct and indirect effects of chemical admixture exposures in environments provides crucial data for more complete risk assessments.

\section{BEyond GLYPHOSATE}

Pending the 2022 glyphosate renewal, scholars and policymakers may need to broaden the horizon of the conversation and focus on some fundamental questions relating to the future trajectories of pesticides. Glyphosate may be on its way out. While it is quite possible given the snowballing rejection of glyphosate by a number of EU Member States (Austria has tabled a ban, Germany is phasing it out, etc.), we have every reason to remain vigilant regarding how agrochemical industry giants may pivot on glyphosate to replace it with even less tested and potentially even more harmful substitutes. As with DDT, which the USA banned in 1974 thanks to the awarenessraising work of Rachel Carson regarding the chemical's long-term biotoxicity, the cure turned out to be almost worse than the disease. Following a pattern that has come to be termed "regrettable substitution", ${ }^{43}$ DDT was originally introduced as a substitute for toxic lead arsenate. When DDT was banned, chlorpyrifos became its ersatz. Numerous studies on chlorpyrifos demonstrate that chronic exposure to it and other organophosphates causes neurodevelopmental toxicity. ${ }^{44}$ While Dow Chemical had already conducted research on the neurodevelopmental toxicity of chlorpyrifos in 1989 , it concluded in its study that there were no statistical differences in harm between workers exposed to organophosphates and those who were not exposed. However, when these same data were reassessed in 2008 by a team of Stanford neuroscience researchers, they found "incredible amounts of elementary science mistakes, including arbitrarily rejecting results, failing to pursue near-significant findings, and various logical errors". ${ }^{45}$ In 2000, the US EPA settled with Dow Chemical to phase out residential chlorpyrifos use while allowing it to continue being used extensively in commercial agrobusiness. Only chlorpyrifos' manufacturer, Dow Chemical, disagrees with what is otherwise a unanimous scientific consensus. ${ }^{46}$

This cascading problem of regrettable substitution represents a more general pattern in chemical regulation. The recent film The Devil We Know underscores the ubiquity of the problem. It documents how DuPont and 3M potentially poisoned the people and animals of Ohio Valley, even though it arguably knew of the teratogenicity of the chemical C-8 (a member of the class of chemicals known as per- and poly-fluoroalkyl substances (PFAS, PFOS and PFOAs) with non-stick properties used in Teflon ${ }^{\mathrm{TM}}$, ScotchGuard ${ }^{\mathrm{TM}}$

\footnotetext{
43 J Allen, "Stop Playing Whack-a-Mole with Hazardous Chemicals" (Washington Post, 15 December 2016) $<$ https://www.washingtonpost.com/opinions/stop-playing-whack-a-mole-with-hazardous-chemicals/2016/12/15/ 9a357090-bb36-11e6-91ee-1adddfe36cbe_story.html> (last accessed 16 December 2019).

44 MF Bouchard et al, "Prenatal Exposure to Organophosphate Pesticides and IQ in 7-Year-Old Children" (2011) 119 Environmental Health Perspectives 1189

45 C Lee, "The Chlorpyrifos Controversy" (McGill University Office for Science and Society, 7 June 2017) <https:// www.mcgill.ca/oss/article/environment/chlorpyrifos-controversy> (last accessed 16 June 2020); see also X Hu, "The Most Widely Used Pesticide, One Year Later" (Science in the News, 17 April 2018) <http://sitn.hms.harvard.edu/flash/ 2018/widely-used-pesticide-one-year-later/> (last accessed 16 December 2019).

46 ibid; Z Teirstein, “Trump's EPA Just Gave a Controversial Pesticide the Green Light" (Grist, 18 July 2019) $<$ https://grist.org/article/trumps-epa-just-gave-a-controversial-pesticide-the-green-light/> (last accessed 16 June 2020).
} 
and other products) as early as $1981^{47}$ because it worried that any chemical it might substitute for C-8 (which currently is in the blood of over $99.7 \%$ of Americans) would possibly be even more toxic. ${ }^{48}$ Thus, in this Special Issue, the authors sought not to compartmentalise glyphosate as an outlier in risk regulation, but instead to position it as indicative of long-standing dysfunctional frameworks of chemical and agrochemical decision-making processes regarding public safety.

Documenting these patterns of iatrogenic chemical regulation is insufficient. The studies in this Special Issue aim to provide a roadmap to rethinking the chemical treadmill that has reproduced new harms with every iteration rather than moving towards green chemistry or a toxic-until-proven-safe preventative health model.

47 RD Ingalls, "C8 Perfluorooctonate - Employee Communication Package" (UCSF 1981) DuPont Confidential Document <https://www.industrydocuments.ucsf.edu/chemical/docs/\#id=kypw0228> (last accessed 26 June 2020).

48 S Soechtig and J Seifert, The Devil We Know (Los Angeles, CA, Atlas Films 2019) < http://www.imdb.com/title/ tt7689910/> (last accessed 20 June 2020). 